\title{
CHARACTERIZATION OF FIVE SUNFLOWER VARIETIES CULTIVATED IN BRAZIL
}

\author{
LEOPOLD HARTMAN * \\ ROSEMAR.ANTONIASSI * \\ SUELI PEREIRA FREITAS **
}

\begin{abstract}
Neste trabalho foram determinados os principais índices de qualidade do óleo de cinco variedades de girassol. Amostras das sementes integrais e descascadas foram analisadas quanto à sua composição centesimal e submetidas a processo de extração com éter de petróleo para quantificação e caracterização do óleo. A cor verde escura observada na água, após classificação das amêndoas trituradas, indica que o ácido clorogênico é parcialmente removido durante a etapa de flotação em meio aquoso. Observou-se considerável diferença entre os índices de acidez dos óleos obtidos a partir de sementes integrais e descascadas devido, provavelmente, ao maior teor de ácido clorogênico nas sementes integrais. Os óleos obtidos a partir das sementes descascadas apresentaram melhores índices de qualidade que aqueles obtidos a partir da semente com casca. Dentre as cinco variedades analisadas apenas a M737 apresenta restrições para aplicação industrial sem pré-tratamento para remoção das cascas, devido à alta acidez no óleo obtido a partir da semente integral. Esta variedade apresentou intensa cor verde-escuro na casca o que compromete o uso da torta, tanto para consumo humano como para ração. Os índices de qualidade do óleo das demais variedades diferem pouco entre si. Óleo com elevado teor de ácidos graxos monoinsaturados foi obtido a partir das variedades M737 e DK180, respectivamente 42 e 40\%. A variedade E-122-V2000, geneticamente melhorada pela Embrapa, foi a que apresentou melhores características para processamento industrial dada sua maior proporção de amêndoa (61\%) e alto teor de óleo na amêndoa $(47,83 \%)$ e poderia ser indicada não fosse sua menor produtividade, $1208 \mathrm{Kg} / \mathrm{ha}$ de acordo com dados fornecidos pela Embrapa-Soja.
\end{abstract}

* D.Sc., Pesquisador III, Empresa Brasileira de Pesquisa Agropecuária (EMBRAPA) Agroindústria de Alimentos, Guaratiba, Rio de Janeiro.

* D.Sc., Pesquisador Visitante, Fundação de Amparo a Pesquisa do Rio de Janeiro (FAPERJ), Rio de Janeiro. (e-mail:sue@ctaa.embrapa.br). 
The sunflower oil, with world production of 9.3 million tons in 1997, is the fourth more consumed oil in the world, surpassed only by soybean oil, palm oil and canola oil (4). Prompted by nutritional recommendations to consume fats high in monounsaturated acids, companies are developing sunflower oil with specific fatty acid profile. Sunflower oil typically contains $66-72 \%$ linoleic acid, $16-20 \%$ oleic acid, $11-12 \%$ saturated acids, and less than $1.0 \%$ linolenic acid (6). According to HAUMANN (6), the high oleic oil obtained from modified genotypes may be the key to the future of sunflower. Although the sunflower oil production in Brazil is incipient, the industrial interest in its production is growing due to its internal market demand that increased significantly from 1993 to present date. In this period its sale increased from 4 to 40.000 tons (8).

EMBRAPA has promoted technological support for development of this culture in Brazil (7). The Embrapa Soja introduced the EMBRAPA 122V2000 variety and intends to put on the market new more productive varieties. Sunflower seed is a potential source of oil and vegetable protein. However, the potential use for human consumption is limited due to the unfavorable color development resulting from protein interaction with chlorogenic acid (CGA), a phenolic compound present in the seed $(3,9)$. This acid oxidates and produces quinones and covalent links with proteins, reducing consequently their biodisponibility (9). Aqueous processing of sunflower seeds prior the oil extraction removes the CGA up to $88 \%$ and improves the oil and meal quality $(3,9)$. The dehulling of sunflower seeds is used in industrial processing, aiming to remove the fiber and the wax, to increase the oil yield and to improve the oil and meal qualities (11).

The objective of the present work is to investigate the characteristics of five varieties of sunflower seeds cultivated by Embrapa Soja, to compare the oil quality index from integral and dehulled seeds, the fatty acid composition of the oils and to select the most promising variety for food applications.

\section{MATERIAL AND METHODS}

\subsection{RAW MATERIALS}

Five varieties of sunflower seeds cultivated in Londrina - PR (Brazil) by Embrapa Soja were used as raw materials. 


\subsection{SAMPLE PREPARATION AND METHODS OF ANALYSIS}

\section{- Dehulling}

The seed dehulling was preceded by a thermal treatment in a pilot dryer using hot air at $70^{\circ} \mathrm{C}$ during 1 hour. The seeds were broken in hammer mills and the hulls removed by flotation in aqueous medium. After the separation step the kernels were dried using hot air at $40^{\circ} \mathrm{C}$.

\section{- Proximate analysis}

Moisture, protein, fiber, and ash content were determined according to AOAC methods (1). The carbohydrates were calculated by difference.

\section{- Oil content}

Oil from integral and dehulled seeds was extracted in Butt apparatus using light petroleum. The solvent was removed under vacuum, according to AOCS (2).

\section{- Chemical characteristics}

Peroxide values and acidity (FFA) of the oils were obtained by the AOCS methods (2). Saponification and iodine values were calculated from fatty acid composition.

\section{- Determination of the fatty acid composition}

The fatty acid composition was determined by gas chromatography of methyl esters prepared according to HARTMAN \& LAGO (5). The fatty acid analysis was performed on a HP5890 gas chromatography equipped with a fused silica capillary column SP2340 $(60 \mathrm{~m} \times 0.32 \mathrm{~mm} \times 0.25 \mu \mathrm{m})$. The temperature program was $150{ }^{\circ} \mathrm{C}$ up to $220^{\circ} \mathrm{C}$ at a rate of $2{ }^{\circ} \mathrm{C} / \mathrm{min}$. Sample dilution was $2 \%$, the volume injected was $1 \mu \mathrm{L}$ and the carrier gas was $\mathrm{H}_{2}$ at $2.26 \mathrm{~mL} / \mathrm{min}$.

\section{RESULTS AND DISCUSSION}

The agronomic characteristics of sunflower seeds genotypes were determined by different laboratories of the Official Net for Sunflower Genotypes Evaluation. The M734 variety presented the highest productivity and the highest oil yield/ha according to the estimated average data (Table 1). 


\section{TABLE 1 - AGRONOMIC CHARACTERISTICS OF SUNFLOWER SEEDS - ESTIMATED AVERAGE FROM THE DATA PUBLISHED BY OFFICIAL NET FOR SUNFLOWER GENOTYPES EVALUATION (7)}

\begin{tabular}{ccc}
\hline GENOTYPES & YIELD (kg/ha) & OIL YIELD (kg/ha) \\
\hline E122- V2000 & 1208 & 584 \\
DK180 & 1655 & 659 \\
M734 $^{2}$ & 1790 & 816 \\
M737 & 1383 & 574 \\
M740 & ND & ND \\
\hline
\end{tabular}

1 Variety developed by Embrapa Soja (7).

2 Variety cultivated by Embrapa Soja (7).

$\mathrm{nd}=$ Not detected

The percentual proportions of kernels and hulls of the five varieties appear in Table 2. The varieties E122-V2000 and M740 presented higher proportion of kernels (61\%) than the others did (42 to 52\%). Table 3 presents the chemical composition of the kernels of sunflower seeds. All varieties have high protein and carbohydrates contents, ranging from 18 to $22 \%$ and from 15 to $20 \%$, respectively.

TABLE 2 - PERCENTUAL PROPORTIONS OF KERNELS AND HULLS OF THE FIVE VARIETIES OF SUNFLOWER SEEDS (DEHULLED IN PILOT EQUIPMENT)

\begin{tabular}{cccccc}
\hline & E122- V2000 & DK180 & M734 & M737 & M740 \\
\hline KERNELS \% & 61.05 & 48.94 & 42.49 & 51.77 & 60.70 \\
HULLS \% & 39.95 & 51.06 & 57.51 & 48.23 & 39.30 \\
\hline
\end{tabular}

TABLE 3 - PROXIMATE COMPOSITION, IN g/100 g, OF SUNFLOWER DEHULLED SEEDS

\begin{tabular}{ccccccc}
\hline & MOISTURE & OIL & PROTEIN & ASH & FIBER & $\begin{array}{c}\text { CARBOHY- } \\
\text { DRATES* }\end{array}$ \\
\hline E122 - V2000 & 5.87 & 47.83 & 22.16 & 3.16 & 2.02 & 18.96 \\
DK180 & 5.18 & 54.80 & 18.82 & 3.21 & 1.97 & 16.02 \\
M734 & 5.45 & 53.41 & 20.18 & 3.48 & 2.01 & 15.47 \\
M737 & 4.41 & 52.59 & 20.62 & 3.06 & 2.30 & 17.02 \\
M740 & 5.80 & 50.02 & 18.34 & 3.69 & 2.32 & 19.83 \\
\hline
\end{tabular}

* By difference.

The oil content of sunflower integral seeds and kernels, peroxide values, and acidity of the oils are shown in Tables 4 and 5 . The oil content in the kernels are higher (48-55\%) than in the seeds (35-42\%) due to the poor oil content in the hulls. The results obtained at EMBRAPA laboratories (Table 
4) and the estimated average data by different laboratories (Table 1) do not significantly differ according to statistical analysis at $95 \%$ of probability (ANOVA).

Although the CGA was not measured, the green color was observed in all varieties and a dark green color in the M737 variety. The color change denoted the presence of CGA, which was partially removed by water during the stages of kernels classification. There was a considerable difference between the acidity of the seeds and the kernel oils (Table 4). The first one is higher, probably due to the high content of chlorogenic acid (CGA) in the integral seeds. The peroxide values and acidity were lower than AOCS specification for crude oils with the exception of the oil obtained from integral M737 seeds that presented a high acidity of $19.08 \mathrm{mg} \mathrm{KOH} / \mathrm{g}$. This high value would produce a very high refining loss.

The content of CGA was higher in the kernel than in the hulls, for two varieties of sunflower seeds cultivated in Brazil (10). However, this result is contrary to the obtained by DOMINGUEZ et al. (3). The content of CGA of the varieties cultivated by EMBRAPA will be determined in future accomplishments.

As can be seen in Tables 2 and 4, EMBRAPA-122-V2000 variety showed the highest content of kernels (61\%) and the high quantity of oil $(39.41 \%)$. Therefore it would be the preferable variety if its agronomic yield (1208 $\mathrm{kg} / \mathrm{ha}$ ) and oil yield (584 $\mathrm{kg} / \mathrm{ha}$ ) were not so low. At the moment it seems that the most promising variety on economical grounds is the variety M734 because of its average productivity and oil yield are 1790 and $816 \mathrm{~kg} / \mathrm{ha}$, respectively (Table 1 ).

\section{TABLE 4 - OIL CONTENT AND QUALITY INDICES OF SUNFLOWER SEEDS AND KERNELS}

\begin{tabular}{lllllll}
\hline VARIETIES & OIL \% & & $\begin{array}{l}\text { PEROXIDE } \\
\text { MEQ/kg }\end{array}$ & VALUE & ACIDITY MGKOH/g \\
& SEEDS & KERNELS & SEEDS & KERNELS & SEEDS & KERNELS \\
\hline E122- V2000 & 39.41 & 47.83 & 0.42 & 1.05 & 2.72 & 0.18 \\
DK180 & 35.76 & 54.80 & 0.31 & 0.77 & 2.78 & 0.14 \\
M734 & 36.99 & 53.41 & 0.51 & 0.65 & 1.92 & 0.20 \\
M737 & 42.36 & 52.59 & 0.46 & 0.28 & 19.08 & 1.12 \\
M740 & 34.95 & 50.02 & 0.49 & 0.66 & 5.14 & 0.28 \\
\hline
\end{tabular}

1 AOCS specification for crude oil: less than $10 \mathrm{meq} / \mathrm{kg}$.

2 AOCS specification for crude oil: less than $4 \mathrm{mgKOH} / \mathrm{g}$.

The fatty acid composition of the oils extracted from dehulled sunflower seeds is shown in Table 5. From these results the saponification and iodine 
values of oils were obtained by calculation. As can be inferred (Table 5) the sunflower oils obtained from the analyzed varieties presented a higher proportion of oleic acid (33-42\%) than conventional sunflower oil (16-20\%) and also lower total of saturated fatty acids (10\%) and can be, therefore, as competitive as canola oil.

\section{TABLE 5 - THE FATTY ACID COMPOSITION FROM DEHULLED SUNFLOWER SEED OILS}

\begin{tabular}{lllllll}
\hline & E122- & DK180 & M734 & M737 & M740 & CODEX ${ }^{1993}$ \\
& V2000 & & & & \\
\hline ALIMENTARIUS
\end{tabular}

$\mathrm{NI}=$ Not identified

Finally, it is worth pointing out that the very low acidity of the oil extracted from dehulled seeds, which according to Table 4 is below $0.30 \mathrm{mg} \mathrm{KOH} / \mathrm{g}$, excepting to M737 variety $(1.12 \mathrm{mgKOH} / \mathrm{g})$.

\section{CONCLUSION}

From the five varieties of sunflower seeds analyzed we can conclude: 
- the E-122-V2000 is the most promising for industrial processing due to its highest content of kernels (61\%) and high quantity of oil (39.41\%) and would be therefore the preferable one if its productivity yield (1208 $\mathrm{Kg} / \mathrm{ha}$ ) was not so low;

- the oil from integral variety M737 presented high acidity $(19.08 \mathrm{mg}$ $\mathrm{KOH} / \mathrm{g})$. This variety has the highest oleic (42\%) content and would be selected for industrial application if previously removed the hulls;

- the acid values of the oils extracted from dehulled seeds is, in some cases, less than $0.1 \%$. The extraction of oils from the kernels simplifies the refining process of the oils and improves the quality of the meal;

- the more promising varieties for producing high level of monounsaturated fatty acids oil are M737 and DK180;

- the aqueous enzymatic extraction of the sunflower oil would be investigated in the future in order to quantify the CGA removed during aqueous treatment.

\begin{abstract}
The oil quality indices of five varieties of sunflower seeds cultivated in Brazil were determined. The composition of integral and dehulled seeds was determined and the oil present in the samples was extracted with light petroleum. The dark color observed in the meal of all varieties denotes the presence of chlorogenic acid (CGA) in the seeds. The darkening of the water was also observed during the stage of classification of kernels by flotation, indicating that CGA is partially removed in aqueous media. The acidity of oils from integral and dehulled seeds showed a significative difference probably due to the high content of CGA in the integral seeds. Dehulled seeds produced better quality oils. The M737 variety is not recommended for industrial application without pretreatment for removing the hulls due to the high acidity of the oil obtained from integral seeds. The oil quality indices exhibited small differences among the varieties. The higher content of monounsaturated fatty acids was observed in M737 and DK180 oils, respectively 42 and $40 \%$. The E-122-V2000 seems to be the most promising variety for industrial processing due to its highest content of kernels (61\%) and high quantity of oil $(39.41 \%)$. Therefore, it would be the preferable variety but its productivity, $1208 \mathrm{~kg} / \mathrm{ha}$ according to Embrapa Soja, is comparatively low.
\end{abstract}

\title{
REFERENCES
}

1 AOAC. Official methods of analysis of the Association of Official Analytical Chemists. 40.ed. Washington, DC, 1995. cap.33, p. 10.

2 AOCS. Official methods and recommended practices of the American Oil Chemists' Society. Champaign, IL, 1996. Sections: Aa 4-38, Ca 5a-40, Cd 8-53. 
DOMINGUEZ, H., NUNEZ, M.J., LEMA, J.M. Eliminación de ácido clorogênico durante el procesado acuoso de las almendras de girasol. Grasas y Aceites, v. 44, n. 4-5, p. 235-242, 1993.

4 GOOD, C.M. Latin American oil consumption increasing. INFORM, v. 5, n. 10, p. 1102-1116, 1994.

5 HARTMAN, L., R.C.A, LAGO. Rapid preparation of fatty acid methyl esters from lipids. Lab. Practice, v. 22, p. 475-476, 1973.

6 HAUMANN, B.F. Modified oil may be key to sunflower's future. INFORM, v. 5, n. 11, p. 1198-1210, 1994.

7 LEITE, R.M.V.B.C., ARIAS, C.A.A., OLIVEIRA, M.F. Avaliação de genótipos de girassol. Rio de Janeiro : Embrapa Soja, 1998. $116 \mathrm{p}$.

8 PINAZZA, L.A., ALIMANDRO, R. Complexo de oleaginosas. Agroanalysis, v. 18, n. 7, p. 44-50, julho 1998.

9 REGITANO d'ARCE, M.A.B., GUTIERREZ, E.M.R., GUNTHER, P.A.S., LIMA, U.A. Cinética da extração do ácido clorogênico de tortas de girassol com etanol. Ciência e Tecnologia de Alimentos, v. 14, n. 2, p. 149-159, 1994.

10 REGITANO d'ARCE, M.A.B., LIMA, U.A. Emprego de álcool etílico na extração de óleo de sementes de girassol (Helianthus annuus). Ciência e Tecnologia de Alimentos, v. 7, n. 1, p. 1-14, 1987.

11 VENKTESH, A., PRAKASH, V. Low molecular weight proteins from sunflower seed: effect of acid butanol treatment on the physicochemical properties. Journal Agric. Food Chem., v. 41, n. 2, p. 193-198, 1993.

\section{ACKNOWLEDGMENT}

The authors are grateful to Dra. Regina M. Vilas Bôas de Campos Leite of the Embrapa Soja for sunflower seeds supply and to Dra. Regina Celi Araújo Lago for suggestions. One of the authors (FREITAS, S.P.) thanks the research fellowship provided by FAPERJ Fundação de Amparo a Pesquisa do Rio de Janeiro (Brasil). 